\title{
Spatial Variability of Chosen Soil Properties on Mountainous Area on Example of the Kasińczanka Stream Basin, Western Carpathians
}

\author{
Edyta Kruk' ${ }^{1}$, Marek Ryczek ${ }^{1 *}$, Sławomir Klatka' ${ }^{1}$, Magdalena Malec ${ }^{1}$ \\ 1 Department of Land Reclamation and Environmental Development, Agriculture University of \\ Krakow, Al. Mickiewicza 24/28, 30-059 Krakow, Poland \\ * Corresponding author's e-mail: rmryczek@cyf-kr.edu.pl
}

\begin{abstract}
The phenomenon of erosion on mountain and submontane areas influences directly on high variability of soil properties. In the work there were presented results of analysis of spatial variability of bulk density, total porosity, organic matter content and saturated hydraulic conductivity, on eroded slopes of the Kasińczanka stream basin. Geostatistical analysis was carried out using the kriging method, based on irregular network, consisted of 52 points, situated by means of the GPS. Taking into account the calculated variability coefficient it was stated, that on the investigated area, the most flexible spatially was saturated hydraulic conductivity, while the less flexible turned out total porosity. Using the determined models of semivariance, the maps of spatial variability of chosen parameters were drafted. It was stated that high value of variance influenced on higher smoothing of spatial distribution in interpolation. Results of geostatistical analysis will allow to find locations for new measuring points, what has substantial significance in mountain areas, for precision analysis of soil properties. Based on the obtained results, it can be stated that the kriging method may be useful tool for determination spatial variability analysis of soil properties on an areas of mountain basins.
\end{abstract}

Keywords: spatial variability, semivariogram, krigring, geostatistics

\section{INTRODUCTION}

The physical, water and chemical properties of both soils and waste are characterized by spatial variability [Boroń et al. 2016, Duffera et al. 2007, Klatka et al. 2016, Medina et al. 2017, Najafian et al. 2012, Tola et al. 2017, Xiong et al. 2015]. The anthropogenic activity influences this variability [Barik et al. 2014, Bogunovic et al. 2017, Klatka et al. 2015, Rosemary et al. 2017, Usowicz and Lipiec 2017, Wei et al. 2009]. Particularly, differentiation of soil properties occurs on slope areas as a result of water erosion [Halecki et al. 2017]. This problem, occuring on lowland areas, was investigated by many authors [Rejman et al. 1998, Williams et al. 1984, Stach 1998]. However, such investigations on areas of mountainous basins were carried out on a small scale. The direct consequence of the evaluation pertaining to the spatial variability of soil environment proper- ties may be the lack of agrotechnical measures, which are not adapted to the predominant conditions [Usowicz et al. 2004]. The knowledge on the spatial variability of soil properties in mountainous stream basins has the basic significance in the determination of the actual conditions of plant growth and development. It is influenced by the phenomena resulting from the processes having relationship with topography and land use [Pennock and De Jong 1987]. Under the mountainous conditions, the land use is subjected to a high degree to configuration and climatic as well as soil conditions. As a result of erosion processes, the agricultural fields on such areas are characterized by high spatial variability of soil properties, which is influenced by numerous factors. The real variability is virtually never linear. That is why there is a need for using interpolation methods, which give better possibility of recognizing the soil properties regarding the specified charac- 
ter of spatial variability. One of such methods is kriging, which allows to determine the mean value of a given variable property in any part of the considered area and to find a location for new measuring points, which will narrow the section of estimation to the highest degree. The spatial variability of soil properties is most often investigated based on the samples taken in regular or irregular measurements [Klatka 2009].

The aim of this work was to conduct the analysis of spatial variability of selected soil properties on the area of a mountain basin using the geostatistical kriging method.

\section{MATERIALS AND METHODS}

The investigations were carried out on the Kasińczanka stream basin, extending over the area of $48,54 \mathrm{~km}^{2}$, located in the Limanowa administrative district, Mszana Dolna community (Small Poland voivodship). The main stream, with the length of $17,74 \mathrm{~km}$, constitutes the inflow of the Raba river. The basin is closed by uplifts belonging to the Mesoregion of the Beskid Wyspowy - slopes of the mountains: Lubogoszcz (967 m a.s.1.), Śnieżnica (1005 m a.s.1.), Wierzbanowska (774 m a.s.1.), Dzielec (607 m a.s.1.) and slopes of Kiczara (710 m a.s.1.). The study work was based on the cartography analysis of the topographic map 1:5000, Digital Elevation Model (DEM) of raster resolution $5 \mathrm{~m}$, and orthophotomap 1:10000, using the MapInfo Professional 15.0 [MapInfo 2002] and the Surfer 8 [Golden 2002] software.

Within the framework of the field investigations on the area of the Kasińczanka stream basin, 52 samples of soil were taken from the upper layer $(0-10 \mathrm{~cm})$ in three replications. The location of points is presented in Figure 1b. In the course of laboratory investigations, the following soil properties were determined: bulk density, total porosity, organic matter content and saturated hydraulic conductivity. The physical properties (bulk density and total porosity) were determined using the rings of $100 \mathrm{~cm}^{3}$ volume [Mocek et al. 1997]. Saturated hydraulic conductivity was determined in laboratory, using the method of hydraulic pressure fall, in the the apparatus based on the Darcy law, with controlled pressure height and electronic reading of water volume. Organic matter content was determined using the Turin method, modified by Oleksynowa et al. [1991], consisting in the oxidation of humus by potassium bichromate $\left(\mathrm{Cr}^{6+}\right)$.

The following statistical measures were calculated with the aim of characterizing the investigated lithogenic parameters and carrying out preliminary determination of their variability degree [Hellwig 1993]: maximum value, minimum value, median, mean value, variance, standard deviation and variation coefficient. Variation coefficient was determined as measure of variance scattering and standard deviation in a shape of a given characteristic quotient - standard deviation and mean value of the given characteristic, expressed in percent. The results were presented in Table 1. Spatial variability of the investigated soil properties was determined using the kriging method. This method allows to estimate the confidence intervals of estimation, determine the mean value in any part of an investigated area and to find location for new measuring points, which to the highest degree will narrow measured in point intervals of distributions. Specifying the term kriging, it should be stated that this is method optimizing estimation of spatially correlated the quantity Z, both in the case of its stationarity and for nonstationarity instances. If we assume that $Z_{i}=Z\left(x_{i}\right)$ is a quantity measured in point $x_{i}(i=1,2 \ldots \ldots . n)$, the problem of point estimation consists in determination of value $Z_{0}$ in point $x_{0}$, where value $Z$ was not measured. By continuous change of location of point $x_{0}$ it is possible to determine all the field of variation of variable $Z$. The analysis was conducted in two stages. In the first one, the correlation of distribution in a shape of the function $\gamma(h)$ stated in geostatistics by empirical semivariogram was determined [Smith et al. 1994]. The obtained results allowed to carry out the quality description of regularities occurring in the differentiation of values of the analyzed parameters. The empirical semivariogram course was determined in the shape of points calculated according to the equation [Oliver and Webster 1986]:

$$
\gamma(h)=\frac{1}{2 m(h)} \cdot \sum_{i=1}^{m(h)}\left[Z\left(x_{i}\right)-Z\left(x_{i}+h\right)\right]^{2}
$$

where: $\gamma(h)$ - value of semivariogram for a distance $h$, $m(h)$ - number of observations outlying of distance $h$, $Z\left(x_{i}\right)$ - value observed in point $x_{i}$ $Z\left(x_{i}+h\right)$ - observed value in point outlying of distance $h$. 
The determined points of empirical semivariograms were described by means of mathematical functions and the theoretical semivariogram was elaborated. The positively determined functions, with zero value in point zero were used for their description. Marx and Thompson [1987] presented the following models: spherical, exponential, Gauss', linear and logarithmic; however, the functions belonging to so called safety class - linear and spherical functions, are used most often. The obtained shape of semivariogram points the kind of spatial correlation of the considered variable. There are two substantial kinds of semivariograms. The first one is characterized by the fact that the variance value increases when the distance $h$ rises up to a maximum value and remains in this state together with the increase of a distance. After the initial increase, value $\gamma(h)$ attains for a given distance $\alpha$ the value equal to variance of a variable. Distance $\alpha$ is called the extent of semivariogram and determines the limit of spatial correlation. Variable $Z$, having semivariogram of this kind, is stationary not only internally, but also has stationarity of the second order. In the second type of semivariograms, variance $\gamma(h)$ is increasing function without limitations. In this case, variance is unlimited and with an increase of distance $h$, attains some boundary value, denoted as $C$. The boundary value is attained exactly or only asymptotically. When semivariogram does not pass the beginning of the coordinate system, then this is called nugget effect, specified as $c_{0}$. This effect may testify that in the case of taking nugget to a sample, other samples - even being very close - will differ by the degree of concentration characterizing the given component.

Maps of spatial variability of the investigated soils were determined using digital procedures - Surfer 8 [Golden 2002]. The input data for this program were determined by means of the STATANAL software [Stein and Staritsky 1993], which allows spatial interpolation on the basis of functions of semivariograms and determined parameters of smoothed models (nugget effect, sill effect), and character of variables. Cutting of isolines was adjusted to the quantity of random error - nugget variance.

\section{RESULTS AND DISCUSSION}

From the point of view of land use and cover, cultural agriculture-forest landscape prevails in the investigated area (Figure 1a). High degree of forestation $(50,19 \%)$ is characteristic to this area. There are mainly coniferous forests, with predominant tree species: Picea abies, Abies alba, Pinus sylvestris, Fagus sylvatica, Betula pendula and Alnus incana. The calculated index of forestation development is equal to 0.487 and is not advantageous for the flows of water in the investigated basin [Lipski et al. 1980]. The area of agricultural production space is used intensively. Small individual farms prevail. Arable lands occupy $63 \mathrm{~km}^{2}$, which corresponds to $42.50 \%$ of the total area. In the structure of land use in individual farms, grasslands (23.27\%) and arable lands (13.78\%) prevail. The remaining $7.31 \%$ of the area is occupied by rural development and traffic grounds. The density of hydrographic network amounts to $2.21 \mathrm{~km} \times \mathrm{km}^{-2}$ (Figure 1d). Mean weighted slope for the entire basin is $16.12 \%$. Soils in the basin were created as a result of weathering of sandstones, shales and marls. Shallow soils, skeletal in the form of light sandy-clay loams prevail. In the higher parts of the basin, on more steep slopes, loamy soils occur, in the form of sandy-clay and sandy loams and clayey silt. In the south-west part of the basin, on lower parts sandy soils in the form of loamy sands, silty and clay silt soils are found. These soils occupy highly eroded places, creating ravines of streams and deeply cut roads, party covered by grasses and shrubs, not forested because of the highly intensive denudation processes (Figure 1c).

The determined values of bulk density fluctuated between 0.75 and $1.53 \mathrm{Mg} \cdot \mathrm{m}^{-3}$, attaining the mean of $1.31 \mathrm{Mg} \cdot \mathrm{m}^{-3}$. The values below 1.25 $\mathrm{Mg} \cdot \mathrm{m}^{-3}$ were determined in the samples taken from forest area. It can be stated that bulk density was influenced by land use. Total porosity ranged between 40.2 and $67.4 \%, 48.48 \%$ on average. Because total porosity influences, among others, the air properties and water permeability, it can be stated that in the case of most points the values are advantageous regarding the resistance to erosion. The content of organic matter in the investigated samples is within the range of $1.85-4.28 \%$. These are typical values for the given subtypes of soils in mountain areas [Mocek 2015]. Regarding this property, the investigated soils are not exposed to erosion. Saturated hydraulic conductivity ranged between $0.84 \times 10^{-3} \mathrm{~m} \cdot \mathrm{d}^{-1}$ and $4.87 \times 10^{-1} \mathrm{~m} \cdot \mathrm{d}^{-1}$. Water permeability plays a great role in surface runoff forming. High values of this parameter $(\geq 8.64$ $\left.\mathrm{m} \cdot \mathrm{d}^{-1}\right)$ show low surface runoff; on the other hand, the lower ones $\left(<0.000864 \mathrm{~m} \cdot \mathrm{d}^{-1}\right)$ cause a higher 


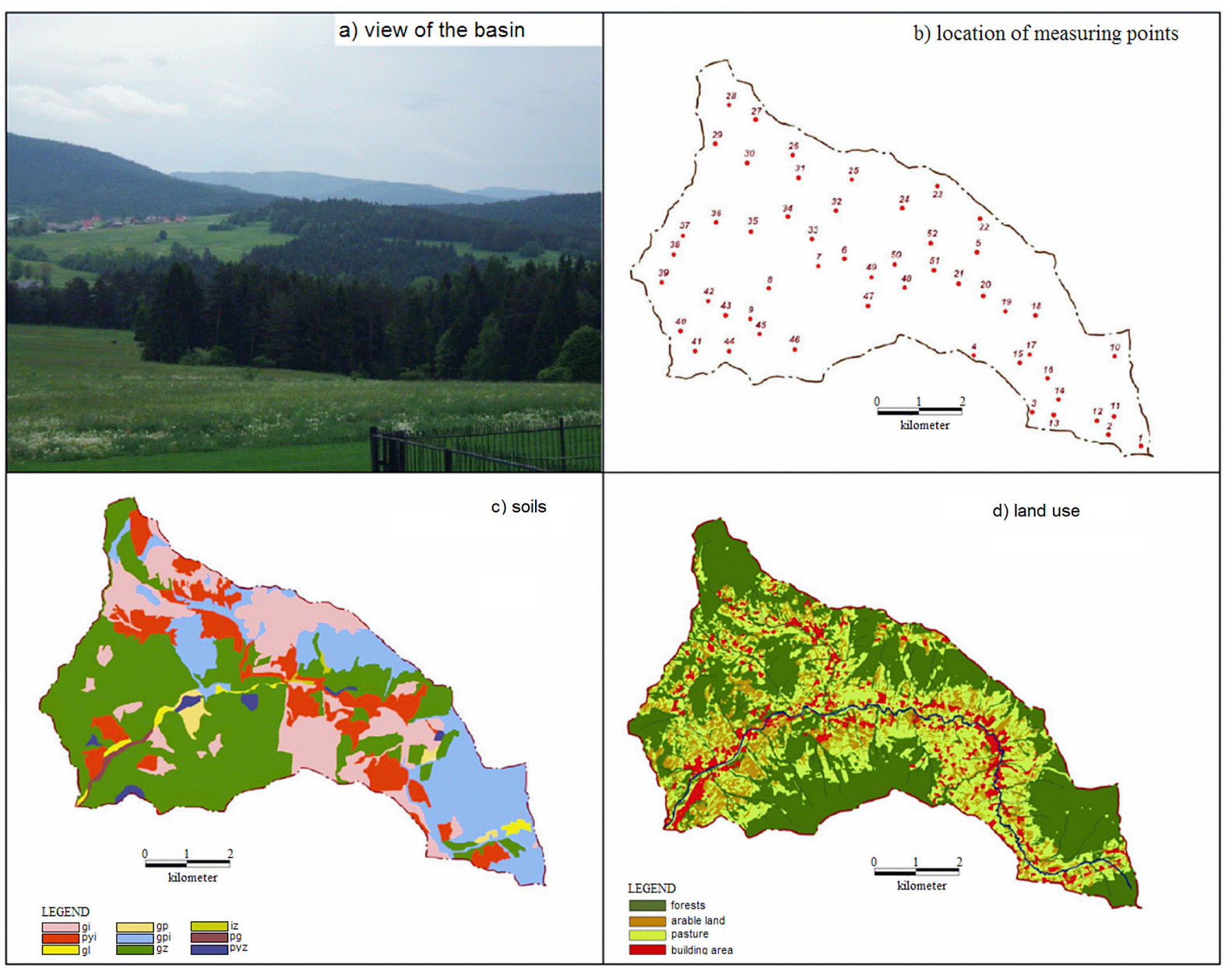

Figure 1. The basin of the Kasińczanka stream: a) view of the basin, b) location of measuring points, c) soils, d) land use of the basin

intensity of surface runoff. The obtained results confirm the possibility of high surface runoff on the basin area.

On the basis of the calculated variability coefficient, it can be stated that on the investigated area, the saturated hydraulic conductivity was the most variable spatially. The obtained results are similar to the ones reported for other authors for mineral soils [Warrick and Nielsen 1980, Somorowski 1993, Brandyk et al. 1995, Klatka and al. 2016], which stated that the lowest variability have bulk density and total porosity, while the highest one have saturated hydraulic conductivity and capillary permeability coefficient. The determined empirical semivariograms were fitted to linear and spherical functions (Figure 3). The values of theoretical semivariograms obtained for saturated hydraulic conductivity, for which fitting by use of above mentioned functions was impossible, constituted an exception. For this property, the values of semivariations formed in a shape parallel to the distance axis. Empirical semivariogram determined for bulk density and organic matter content was fitted using the linear model. In this case, the semivariation decreases with the distance in which it is not possible to establish a limit of spatial correlation as a value, for which semivariation stabilizes. The nugget effect was not determined. The empirical semivariograms determined for total porosity were fitted by means of a spherical model. In these cases, the nugged effect was observed, which testifies the occurrence of variability of a given property in a smaller distance than the one between the measuring points. The occurrence of this effect may be the result of exactness of use of the measurement method. For the semivariograms of the considered soil properties, the limit surface correlation, which amounted $445.12 \mathrm{~m}$, was determined as well. Table 2 presents the parameters of the fitted models.

On the basis of the determined models of semivariation, the maps of spatial variation of the investigated parameters were drafted, using the kriging method. The cut of isolines was adapted to random error - nugget variation. High 
a)

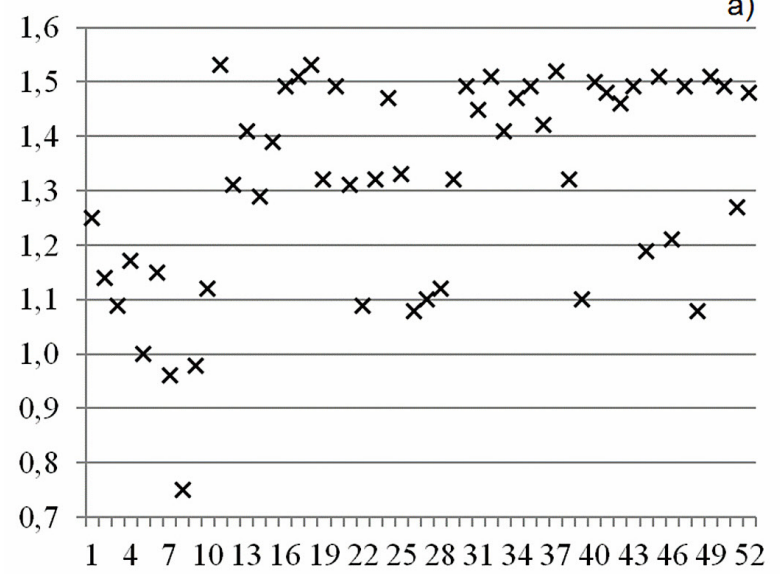

c)

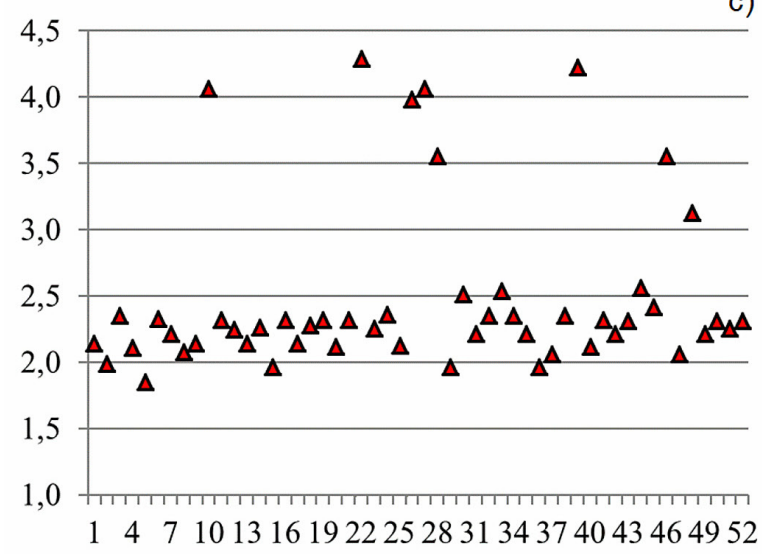

b)

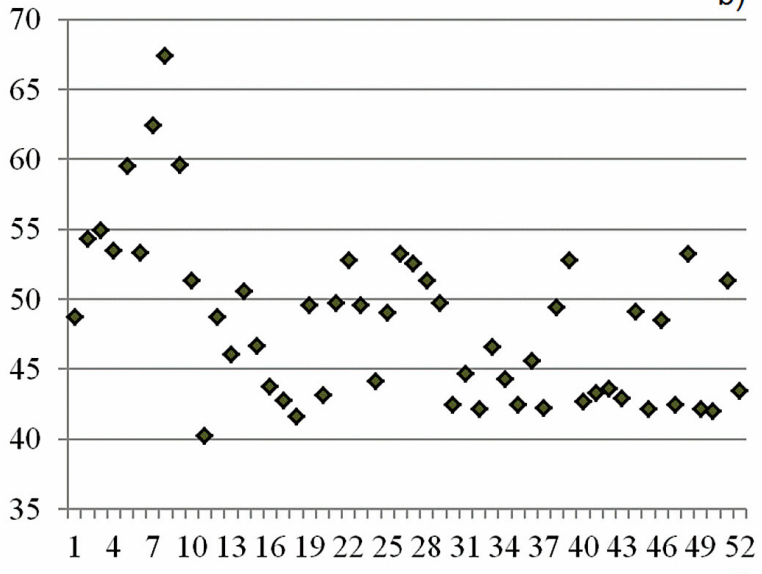

d)

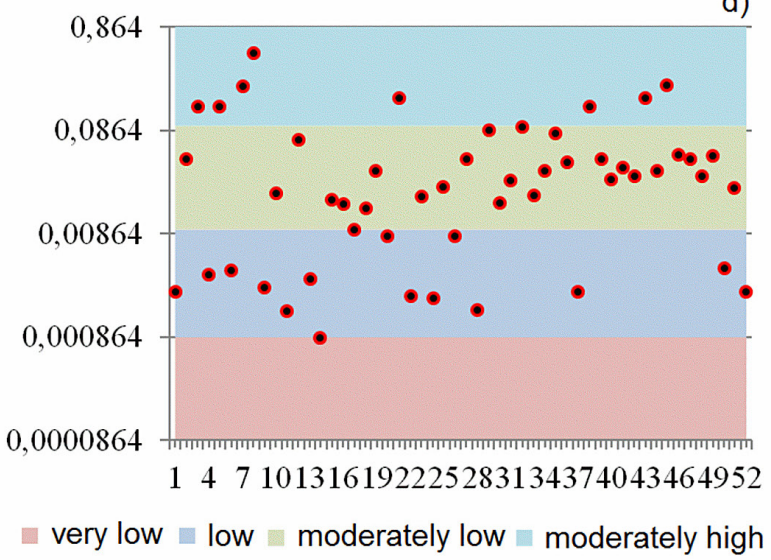

Figure 2. Results of parameters determination: a) bulk density $\left(\mathrm{Mg} \cdot \mathrm{m}^{-3}\right)$, b) total porosity $(\%), \mathrm{c}$ ) organic matter content $(\%), d)$ saturated conductivity coefficient $\left(m \cdot \mathrm{d}^{-1}\right)$

Table 1. The determined statistical measures

\begin{tabular}{|l|c|c|c|c|c|c|}
\hline \multirow{2}{*}{ Investigated parameter } & \multicolumn{7}{|c|}{ Statistical measures } \\
\cline { 2 - 7 } & $\begin{array}{c}\text { Min value } \\
X_{\min }\end{array}$ & $\begin{array}{c}\text { Max value } \\
X_{\max }\end{array}$ & $\begin{array}{c}\text { Mean value } \\
X\end{array}$ & $\begin{array}{c}\text { Variance } \\
V(X)\end{array}$ & $\begin{array}{c}\text { Standard } \\
\text { deviation } \\
\delta(X)\end{array}$ & $\begin{array}{c}\text { Variability } \\
\text { coefficient } \\
\vartheta[\%]\end{array}$ \\
\hline Bulk density $\left(\mathrm{Mg} \cdot \mathrm{m}^{-3}\right)$ & 0.75 & 1.53 & 1.31 & 0.04 & 0.26 & 19.92 \\
\hline Total porosity $(\%)$ & 40.20 & 67.40 & 48.48 & 40.07 & 6.37 & 13.14 \\
\hline Organic matter content $(\%)$ & 1.85 & 4.28 & 2.49 & 0.43 & 0.71 & 28.6 \\
\hline $\begin{array}{l}\text { Saturated conductivity } \\
\text { coefficient }\left(\mathrm{m}^{-1} \mathrm{~d}^{-1}\right)\end{array}$ & 0.00084 & 0.4780 & 0.0618 & 0.0098 & 0.0561 & 90.78 \\
\hline
\end{tabular}

value of variation influenced the greater smoothness of spatial distribution in interpolation using the kriging method. Similar relationships were stated in the investigations carried out by Klatk et al. [2017].

Spatial variability of mineral soils properties using the geostatistical kriging method was the subject of investigations carried out by many authors. Wei et al. [2006] used this method for the evaluation of spatial variability of organic matter content in the north-east part of China. Shao et al. [2006] determined spatial variability of nutrients distribution in soil. Stach [1998], in turn, determined the spatial distribution of arable layer properties on litologically heterogeneous morainal slope. The results of investigations of the afore-mentioned authors show that the geostatistical analysis and maps of spatial variability enable the estimation of the investigated variable value in every point of the considered area and determination of mean value in any part of the area. It allows to find the location for new measuring points, which narrow the estimation intervals of distributions to the highest degree. Taking 
a)
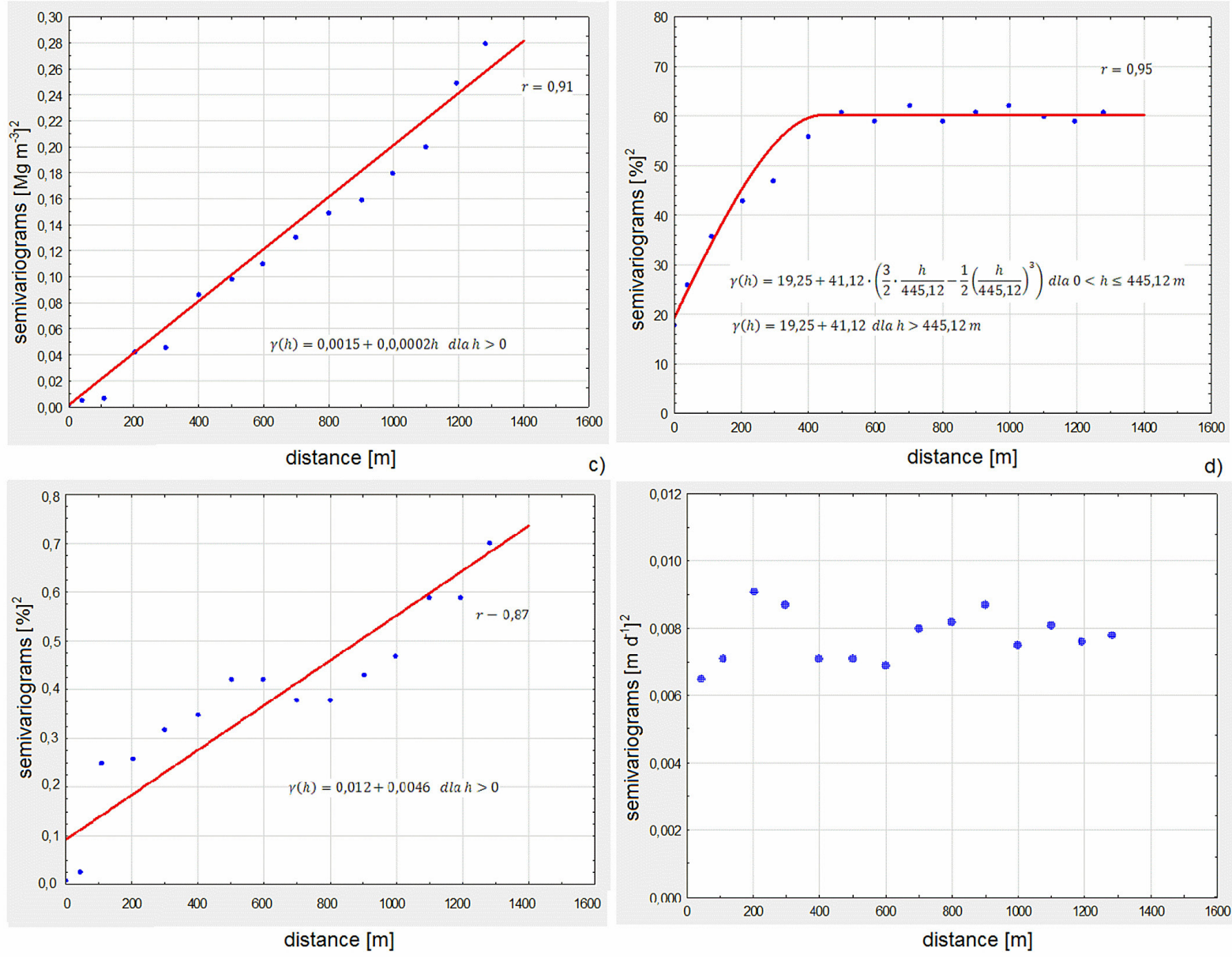

Figure 3. Empirical and theoretical semivariograms: a) bulk density $\left(\mathrm{Mg} \cdot \mathrm{m}^{-3}\right)$, b) total porosity $(\%)$, c) organic matter content $(\%), \mathrm{d})$ saturated conductivity coefficient $\left(\mathrm{m} \cdot \mathrm{d}^{-1}\right)$

Table 2. Parameters of the fitted models

\begin{tabular}{|l|c|c|c|c|c|}
\hline \multicolumn{1}{|c|}{ Soil properties } & Model & Nugget effect. co & Boundary effect. C & Scope. $\alpha[\mathrm{m}]$ & $\begin{array}{c}\text { Correlation } \\
\text { coefficient. } r\end{array}$ \\
\hline Bulk density & linear & 0.0015 & 0.0002 & - & 0.91 \\
\hline Total porosity & spherical & 19.25 & 41.12 & 445.12 & 0.95 \\
\hline Organic matter content & linear & 0.012 & 0.00046 & - & 0.87 \\
\hline Saturated conductivity & - & - & - & - & - \\
\hline
\end{tabular}

into account the erosion processes in mountain streams basins this problem has the basic significance for determination of the sampling distribution for precise analysis of soil properties.

The drafted spatial distribution maps of the investigated properties show their high relation with land use and runoff processes on slopes and the erosion connected with it. Moreover, spatial distribution of the investigated parameters show high dynamics, which - in the case of arable land - is influenced by time that passed by from last tillage treatment.

\section{CONCLUSIONS}

Regarding texture, bulk density and total porosity, the soil on the investigated area is relatively resistant to water erosion. Howeverm low values of saturated hydraulic conductivity point to the possibility of high runoff occurrence. Spatial variability of the investigated soil properties is influenced to a high degree by land use.

The theoretical semivariogram for saturated hydraulic conductivity and limit of spatial correlation were not determined for the investigated 


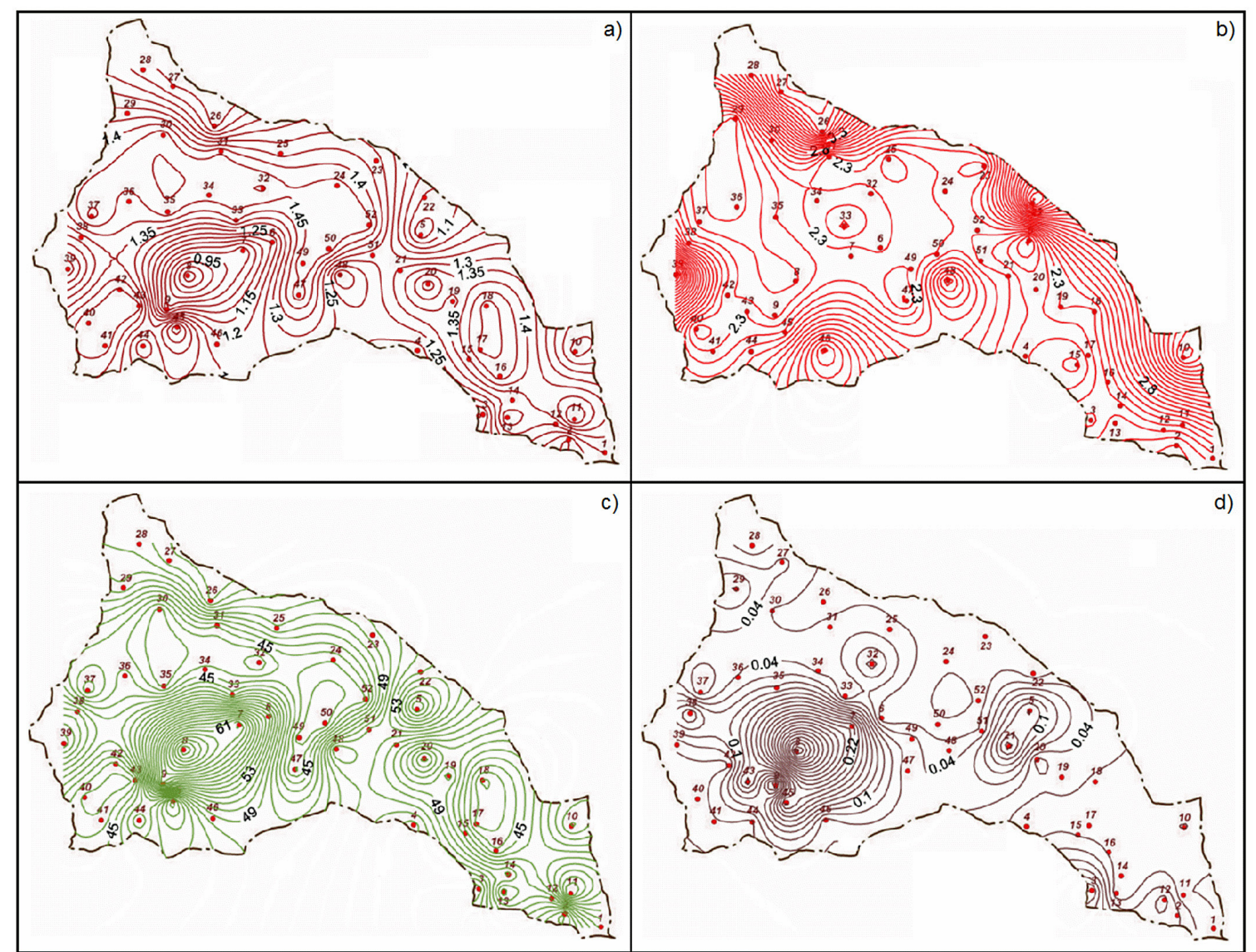

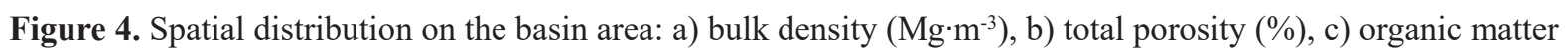
content $(\%), d)$ saturated conductivity coefficient $\left(\mathrm{m} \cdot \mathrm{d}^{-1}\right)$

soils. This is connected with high random variability of these properties. For bulk density and organic matter content, semivariation increased linearly with distance, and it was not possible to determine the limit of spatial correlation as well. In the case of total porosity, the limits of spatial correlation were determined. The nugget effect was observed which may testify the occurrence of variability of a given parameter in a distance lesser that the one between measuring points.

The stated spatial relationship of the investigated soil parameters shows that for their representative description, the statistical evaluation is not sufficient, because of the basic assumption of statistics - independent of samples. Because classical statistics are reliable only beyond the area of spatial dependence that is why significant error may occur within it. The determined relationships of the investigated properties show that during the calculation of basic statistics for a given area, the character of their relations has to be taken into consideration. On the basis of the obtained results, it can be stated that the kriging method may be a useful tool for determination spatial distribution of soil properties in mountainous area.

\section{REFERENCES}

1. Barik K., Aksakal E.L., Islam K.R., Sari S., Angin I. 2014. Spatial variability in soil compaction properties associated with field traffic operations. Catena, 120, 122-133.

2. Bogunovic I., Trevisani S., Seput M., Juzbasic D., Durdevic B. 2017. Short-range and regional spatial variability of soil chemical properties in an agroecosystem in eastern Croatia. Catena, 154, 50-62.

3. Boroń K., Klatka S., Ryczek M., Liszka P. 2016. Kształtowanie się właściwości fizycznych, fizykochemicznych i wodnych rekultywowanego i niezrekultywowanego osadnika byłych Krakowskich Zakładów Sodowych „Solvay”. Acta Scientiarum Polonorum Formatio Circumiectus, 15(3), 35-43.

4. Brandyk T., Gnatowski T., Szatyłowicz J. 1995. Zmienność przestrzenna właściwości fizycznych w glebie torfowo-murszowej. Materiały Sesji Naukowej - Torfoznawstwo w Badaniach Naukowych i Praktyce. IMUZ Falenty, 273-280.

5. Duffera M., White J.G., Weisz R. 2007. Spatial variability of Southeastern U.S. Coastial Plain soil physical properties: Implications for site-specific management, Geoderma, 137, 327-339.

6. Halecki W., Młyński D., Ryczek M., Kruk E., Ra- 
decki-Pawlik A. 2017. The Application of Artificial Neural Network (ANN) to Assessment of Soil Salinity and Temperature Variability in Agricultural Areas of a Mountain Catchment. P. J. Environ. Stud., 26(6), 2545-2554.

7. Hellwig Z. 1993. Elementy rachunku prawdopodobieństwa i statystyki matematycznej. PWN, Warszawa, pp. 313.

8. Klatka S., Malec M., Ryczek M., Boroń K. 2015. Wpływ działalności eksploatacyjnej Kopalni Węgla Kamiennego „Ruch Borynia” na gospodarkę wodną wybranych gleb obszaru górniczego. Acta Scientiarum Polonorum Formatio Circumiectus, 14(1). 115-125.

9. Klatka S., Malec M., Ryczek M., Kruk E., Zając E. 2016. Ocena zdolności retencyjnych wybranych odpadów przemysłowych. Acta Scientiarum Polonorum Formatio Circumiectus, 15(4), 53-60.

10. Klatka S, Zając E, Zarzycki J. 2017. Areal variability of the mineral soil cover in a reclaimed soda waste dumping site. Annals of Warsaw University of Life Sciences - SGGW. Land Reclamation, 49(1), 15-27.

11. Marx D,B., Thompson K.C. 1987. Practical aspect of agricultural Kriging. Arkansas Agricultural Experiment Station Bulletin, 903.

12. Medina H., de Jong van Lier Q., Garcia J, Ruiz M.E. 2017. Regional-scale variability of soil properties in Western Cuba. Soil and Tillage Research, 166, 84-99.

13. Mocek A. 2015. Gleboznawstwo. PWN Warszawa.

14. Najafian A., Dayani M., Montaghian H.R., Nadian H. 2012. Geostatistical Assessment of the Spatial Distribution of Some Chemical Properties in Calcareous Soils. Journal of Integrative Agriculture, 11(10). 1729-1737.

15. Oliver M., Webster R. 1986. Semi-variograms for modelling the spatial pattern of landform and soil properties. Earth Surf Proc Land, 11, 75-92.

16. Pennock, D.J., De Jong, E., 1987. The influence of soil curvature on soil erosion and deposition in hummock terrain. Soil Science, 144 (3), 209-217.

17. Rejman, J., Turski, R., Paluszek, J., 1998. Spatial and temporal variations in erodibility of loess soil. Soil and Tillage Research, 46, 61-68.

18. Rosemary F., Vitharana U.W.A., Indraratne S.P., Weerasooriya R., Mishra U. 2017. Exploring the spatial variability of soil properties in an Slfisol soil catena. Catena, 150, 53-61.

19. Shao W.H.,Jji Y.J.,Lli P.Y., You L.. 2006. Spatial Variability of Soil Nutrients and Influencing Factors in a Vegetable Production Area of Hebei Province in China. Nutr Cycl Agroecosyst, 75, 201-212.

20. Smith J. L., Halvorson J. J., Papendic R.I. 1994. Multiple variable indicator kriging: a procedure for integrating soil quality indicators. Soil Science of America. Special Publication, 35, 52-80.

21. Somorowski Cz. 1993. Współczesne problemy melioracji. Wydawnictwo SGGW, Warszawa.

22. Stach A. 1998. Zmienność przestrzenna właściwości warstwy ornej na niejednorodnym litologicznie stoku morenowym. Bibl Fragm Agron, 4A, 123-142.

23. Stein A., Staritsky I.G. 1993. Spatanal. User's Guide. Geographic Institute RUU. The Netherlands

24. Surfer for Windows. 2002. Golden Software Inc. Colorado, USA.

25. Tola E., Al-Gaudi K.A., Madagundu R., Zayada A.M., Kayad A.G. 2017. Characterization of spatial variability of soil physicochemical properties and its impact on Rhodes grass productivity. Saudi Journal of Bilogical Sciences, 24, 421-429.

26. Warrick A.W, Nielsen D.R. 1980. Spatial variability of soil physical properties in the field. In: Hillel D. Applications of soil physics. New York: Academic Press, 319-344.

27. Usowicz B., Lipiec J. 2017. Spatial variability of soil properties and cereal yield in a cultivated field on sandy soil. Soil \& Tillage Research, 174, 241-250.

28. Usowicz B., Hajnos M., Sokołowska Z., Józefaciuk G., Bowanko G., Kossowski J. 2004. Przestrzenna zmienność fizycznych i chemicznych właściwości gleby w skali pola i gminy. Acta Agrophysica. Rozprawy i Monografie, 3, 90.

29. Wei Y., Bai Y., Jin I., Zhang F., Zhang L., Liu X. 2009. Spatial variability of soil chemical properties in the reclaiming Marine Foreland to Yellow Sea of China. Agricultural Sciences in China, 8(9). 1103-1111.

30. Wei J.B., Xiao D.N., Zhang X.Y., Li X.Z. Li X.Y. 2006. Spatial Variability of Soil Organic Carbon in Relation to Environmental Factors of a Typical Small Watershed in the Black Soil Region, Northeast China. Environ. Monitor Assess. 121, 597-613.

31. Williams, A.G., Ternan, J.L., Kent, M., 1984. Hydrochemical characteristics of Dartmoor hillslope. In: Catchment experiments in fluvial geomorphology, T.P. Burt, D.E. Walling (Eds.), Geobooks, Norwich, 379-398.

32. Xiong Z., Li S., Yao L., Liu G., Zhang Q., Liu W. 2015. Topography and land use effects on spatial variability of soil denitrification and related soil properties in riparian wetlands. Ecological Engineering, 83, 437-443.

33. Zając E, Klatka S., Zarzycki J. 2016. Distribution of woody vegetation on soda waste dumps in relation to spatial variation in selected parameters of the mineral cover. Journal of Ecological Engineering, 17(5), 49-56. 